\title{
Commentary
}

\section{Drawing upon the Wealth of Indigenous Laws in the Yukon}

Darcy Lindberg*

\begin{abstract}
As there is a collective renaissance' in the recognition of Indigenous legal traditions and laws in Canada, this reflection focuses on a "constitutive" approach that non-Indigenous Yukoners can take to law making, in that it explores how the constitutive practices and institutions of Yukon First Nations can be utilized to inform both lawyerly approaches to First Nations law and the interactions of the non-Indigenous Yukon public with Indigenous laws. This reflection explores this in two ways: I) the necessity to view the constitutive and legal practices of Indigenous communities from a broad, normative lens; and 2) how a normative approach provides different fruitful approaches to accessing, understanding, and drawing upon Indigenous laws.
\end{abstract}


When I first travelled to the Yukon in 2013, it was impossible not to be wideeyed as I moved north through broad valleys along the Alaska Highway. It was the vastness of these corridors that had not only my mind alight, but my legal curiosity as well, as I knew that these valleys held law-were storied with it - as the land and waters held the legal traditions of the Indigenous nations whose territories I was travelling over. When I finally arrived in Whitehorse and settled into my articling work, I was prepared for my study of law to be widened in a less conventional manner. As my travel up suggested, my legal study broadened into observations of the plurality of legal systems operating within the territory. In the office, I was mainly thick into territorial and federal law, while I spent the long evenings that first summer out on the lands and waters surrounding Whitehorse, out into the jurisdictions of the local nations.

So my work did not finish in the office. As a Plains Cree visitor to these lands and waters, I had obligations to the Indigenous nations' laws and legal traditions whose territory I was travelling upon. This plurality was, of course, not tidily demarcated. The law practice where I worked was enriched by Indigenous legal traditions overlapping into the four corners of traditional private practice, while the land and waterscapes within traditional territories of Yukon First Nations, whether by imposition or agreement, were marked by territorial or federal law.

The hard work of reconciling legal orders is rooted in communication. With the "renaissance" of Indigenous legal traditions within Canada, First Nations are dealing with common challenges of how to address the imposition of law on the social, economic, legal, and spiritual lives of Indigenous peoples, while ensuring the legal ordering of their communities is recognized and understood by non-Indigenous peoples. ${ }^{2}$ The jurisdictional spaces negotiated through the Final Agreements and Self-Government Agreements (SGAs) in the Yukon have provided the particular challenge of immediacy (in that First Nations are generally under pressure to create legislation) to hold up Indigenous laws and legal traditions. As there is a natural tendency for First Nations to scaffold the jurisdictional territory outlined in the SGAs through legislation, this raises conceptual questions about the utility of enacting First Nation legislation that mimics federal and/or territorial legislation. While there are certainly large benefits from such codification, there are dangers of simply reproducing law the imposition of which has historically harmed or adversely positioned First Nations. Connected to this, there is a significant challenge in utilizing, reforming, adapting, or transforming Indigenous principles, laws, procedures, processes, teachings, and pedagogies into legislation, regulations, or directives. It is the second of these challenges that the rest of this article is concerned with. I argue that, as lawyers, 
we have a duty to engage with Indigenous laws through a constitutive approach. That is, we should encourage and facilitate the raising up of Indigenous legal traditions through an examination of constitutionalism in a broad sense. This reflection introduces Indigenous constitutional and legal theories that broaden our conceptions of law and constitutionalism, and examines how these can inform approaches to Indigenous legal traditions.

\section{Indigenous Constitutional Philosophies and Theories}

I am basing this reflection on the following theory of constitutionalism. While the general reader may be more familiar with "constitutionalism" in a Canadian political context, with a constitution comprised of formal and informal understandings like agreements located in founding texts and unwritten time-worn conventions, specific Indigenous constitutions draw from their particular lifeworlds. ${ }^{3}$ For example, I consider the constitutionalism of my home nation (the nêhiyawak, or Plains Cree peoples) as encapsulating a totality of ideals, principles, and aspirations arising out of the ontologies and epistemologies that further a shared understanding of what it means to be nêhiyaw. ${ }^{4}$ This totality is held collectively and can neither be fully understood or directed by an individual. It is also never fixed; as social and legal norms continue to be transformed through contestation and shifting agreements amongst society members, so does nêhiyaw constitutionalism. The decentralized political and legal structure of the nêhiyawak (a governance feature shared by other First Nations) means that other institutions (rather than central enactments and proclamations) are instrumental in carrying out and teaching constitutive principles. ${ }^{5}$ Beyond written texts ${ }^{6}$ or customary practices, ${ }^{7}$ the epistemological and ontological underpinnings of constitutional principles lie within narratives, ${ }^{8}$ songs, ${ }^{9}$ artistic renderings, ${ }^{10}$ ceremonies,${ }^{11}$ spiritual and place names, ${ }^{12}$ kinship models ${ }^{13}$ bundles, ${ }^{14}$ and language. ${ }^{15}$ Like in all polities, there are differences in opinion on the nature of nêhiyaw constitutionalism, and what belongs within its constitutive tradition. ${ }^{16}$ These contestations of what is constitutional principle and ultimately law are vitally important to our legal traditions. They are necessary for law to maintain its legitimacy to its citizenry.

The relationship between the normative constitutional practice within nêhiyaw societies and formal, written, declarative constitutionalism-where the norms serve as a foundation for a written constitution to arise from-is shared by other Indigenous societies and nations. ${ }^{17}$ As I am not a member of a Yukon First Nation, I have refrained from commenting or speculating on particular forms of constitutionalism practised by individual nations. Many self-governing Yukon First Nations have formalized their constitutional norms within written constitutions. In the face of written constitutions, it is important to remember the written form 
is a reflection of a broader constitutionalism. A broad constitutionalism should ring familiar even for the reader who is only familiar with Canadian state law and constitutionalism, as the broad foundations for Indigenous constitutions is also a characteristic shared by Canadian constitutionalism. For example, in considering the question of whether Quebec could unilaterally secede from Canada in Reference Re: Secession of Quebec [1998] 2 SCR, the Supreme Court of Canada notes that:

The Constitution is more than a written text. It embraces the entire global system of rules and principles which govern the exercise of constitutional authority. A superficial reading of selected provisions of the written constitutional enactment, without more, may be misleading. It is necessary to make a more profound investigation of the underlying principles animating the whole constitution, including the principles of federalism, democracy, constitutionalism and the rule of law, and respect for minorities. Those principles must inform our overall appreciation of the constitutional rights and obligations... ${ }^{18}$

So a practitioner who is unfamiliar with the constitutive institutions and practices of a particular First Nation should consider the constitutions of self-governing Yukon First Nations to be broader than the written documents. The urgency the Supreme Court of Canada impresses upon us in our consideration of Canadian constitutionalism, that " $[\mathrm{i}] \mathrm{t}$ is necessary to make a more profound investigation of the underlying principles animating the whole constitution," is no less urgent in our examinations of Indigenous constitutions. ${ }^{19}$

Further, the broad foundation of Canadian and Indigenous constitutions highlights a plurality of the constitutive practices of Indigenous peoples in the Yukon. It also provides potential for non-Indigenous Yukoners to embrace and better understand Indigenous constitutive and legal practices. As John Borrows states, the Canadian constitution is:

An open ended - perpetual work in progress, a living tree. It is comprised of various written texts, an assortment of established conventions, and a diverse array of oral traditions. It is an openended marriage, polyandrous in many ways, allowing for multiple partners. It even has rules that contemplate divorce. In many respects, Canada's constitution is a fluid arrangement, and many people seem to like it that way. ${ }^{20}$ 
Canadian constitutionalism is tangle-rooted-while not fully realized in formal constitutional forums, the influence of Indigenous constitutions on Canadian constitutionalism should make it even moreso. The diverse potential of constitutional pluralism in Canada through further recognition of Indigenous constitutional orders challenges "the conventional court-centric view of early constitution-making in Canada [that] has concentrated on formal British Imperial instruments." 21

The deepening written articulation of the common law and increasingly technocratic nature of the Canadian legal system is further obscuring the unwritten and oral traditions of the Canadian constitution. ${ }^{22}$ This further industrialization provides us with "false constitutional limits." ${ }^{\text {"23 }}$ As Borrows explains:

"[t]he composite nature of Canada's constitution has made it simultaneously easier and more difficult to create greater space for Indigenous governance. Unfortunately, since the entrenchment of Aboriginal and treaty rights in Canada's constitution, it has been harder for Indigenous peoples to throw off false constitutional limits." ${ }^{4}$

In a similar manner, the written constitutions of the eleven self-governing Yukon First Nations raise the danger of false constitutional limits- that all the constitutive practices and norms of a Yukon First Nation are expressed wholly within its respective written constitution. The formalizing of Indigenous law in written law and constitutions overemphasizes written law's authority. This overemphasis provides an environment where legal practitioners (lawyers, judges, students, and academics alike) are the most comfortable. There is a natural tension for practitioners who engage with Indigenous legal traditions to produce work that is understood by a non-Indigenous public but also is faithful to their nation's understanding of constitutions, law, and culture. The increasing formalization of legal traditions provides a false resolution of this tension. Returning to the tensions between legal orders I introduced at the start of this commentary, a recognition of the law's normative roots- that it is a society's practice of living, contesting, and ultimately agreeing on how to coordinate their lives with each other-as the necessary scaffolding that gives declarative law its foundation, will deeply aid the practitioner who engages with Indigenous legal traditions. 


\section{From Constitution to Specific Laws: Methods to Engage with Indigenous Constitutionalism}

Taking this normative constitutional approach, I avoid speculating on the existence of bright lines that demarcate what separates a law versus a social practice or norm, a muddy discourse that may be unresolvable. ${ }^{25}$ In saying this, I do not wish to overrepresent the normative aspect of Indigenous legal orders and constitutionalism. Positivistic law and norms (written and declared law) are undoubtedly prevalent and in many situations the most efficient use of law in the ordering of aspects of Indigenous societies. Written constitutions and legislation have been utilized by Indigenous communities for centuries. ${ }^{26}$ They are an integral tool for centering the governing structures and rights of citizens within Indigenous nations through formal text. ${ }^{27}$ Written constitutions also enshrine fundamental human rights for citizens within their central governments. ${ }^{28}$ The further formal democratization of Indigenous nations has relied upon structures that have increased the authority of elected or recognized leaders and centralized it with them. However, as I have advocated above, the avenues that lawyers must engage in Indigenous legal traditions must be necessarily normative. The jurisdictional space that the Self-Government Agreements may hold for Yukon First Nations creates a tension between enacting legislation while maintaining laws and legal processes that are faithful to First Nations' respective epistemologies.

Engaging in the normative field to source laws is a monumental task, especially for legal practitioners who are trained and experienced in state legal practices. While I will briefly explore methods of engagement below, I note that much of this work does not need to be carried by —and considering the resources it takes for Indigenous communities to utilize lawyers, in many cases should not be done by-the traditional law firm. It is trite to say that the practice of Indigenous legal traditions has been ongoing since time immemorial within Indigenous communities. There have always been legal practitioners, teachers, and legal knowledge holders within communities. There are internal methods for raising up Indigenous legal orders that are not listed below. However, one fruitful avenue for Indigenous nations to hold up their laws has been to engage in research through academic means. Scholarly research has provided Indigenous communities with help in standing up their laws in a more appropriate and costeffective manner than a law office traditionally can. Utilizing the work of Hadley Friedland, I will briefly explore some of the methodologies that academic and research institutes utilize to engage in this supportive work. ${ }^{29}$ My brief survey will include the following avenues toward Indigenous law and constitutionalism: (1) the linguistic approach; (2) the source of law approach; and (3) a storied approach. 
The Linguistic Approach: There are various advocates of using Indigenous languages as a method to articulate Indigenous legal principles and traditions. For example, Anishnaabe jurist Matthew Fletcher, who currently sits as a tribal court judge, advocates a linguistic approach to apply Indigenous legal principles in tribal court cases in the United States. ${ }^{30}$ The linguistic method involves the identification of "an important and fundamental value" held by an Indigenous nation that is "identified by a word or phrase in a tribal language" and to recognize this word as a primary principle. ${ }^{31}$ This principle is then applied to a secondary rule "as necessary, to harmonize outside (positivistic) rules to the tribe's customs and traditions." 32

Dual challenges with any linguistic approach are accessibility and translation. To overcome these challenges, a linguistic methodology requires deep knowledge within a community. Thus, it also requires either a deeper relationship (or commitment to a deep relationality) from a practitioner or researcher to use language as legal resource.

Source of Law Approach: John Borrows developed this approach to address the colonial tendency to view legal actions taken by Indigenous people as merely "customary" in nature. ${ }^{33}$ Borrows links Indigenous laws to five original locations: sacred, natural, customary, deliberative, and positivistic sources. Although it may not be a complete response to the challenge of accessing law beyond positivistic forms, Borrows's sources of law provide a rich conceptual avenue for a practitioner or researcher to orient themselves in their questions about Indigenous communities. Particularly, Indigenous citizenries maintain strong links between ceremonial practices and legal norms. ${ }^{34}$ Relationships to non-human beings and things are often formalized through law. ${ }^{35}$ On-the-land learning is an integral pedagogical tool for sourcing law from the ecological world.

Indigenous communities rely upon both historical and contemporary deliberative processes to make law. Finally, as mentioned above, positivistic processes are an integral part of all Indigenous legal ordering in the Yukon. While an approach through these sources of law can still face the same challenges that the linguistic approach presents regarding accessibility and translation, it provides broad avenues that allow a practitioner to consider social practices they may otherwise ignore. This approach links to the areas where Indigenous laws may reside, which I listed earlier. 
Storied Approaches: Using stories as a resource to access legal principles within Indigenous communities and nations is a historical practice. It also has become the favoured practice for academic institutions. A couple of methods that have arisen from this work are highlighted here. There is an approach that relies upon on a story to be interpreted for its legal processes and decisions. Much like the source of law approach, a community connection may provide an ample background immersion to identify law within a single case, but a deeper knowledge of a community allows for a researcher to fully identify areas of law within a single story.

A critique of using a single story is the lack of interpretive limits. ${ }^{36}$ As Friedland states, "there must be some way to recognize legitimate boundaries for interpretative arguments to take place within." ${ }^{\prime 3}$ She acknowledges that a deep knowledge of a community may resolve this challenge, as an interpreter with this knowledge may be "operating within implicit interpretive limits ... due to ... particular deep cultural knowledge" and "access to family and community connections" in their interpretation..$^{38}$ The adapted case-brief method, an approach favoured by the University of Victoria's Indigenous Law Research Unit, addresses this concern by relying upon an analysis of many stories to identify and restate legal principles. It also relies on the multiple analyses to immerse the researcher within the stories of a community. Through this immersion, the researcher will see trends of the normative practices of a community, leading to a thicker frame of legal analysis. This methodology may only require the use of publicly accessed knowledges, and may only require light relationality.

While taking a storied approach is the most accessible avenue (given the amount of published narratives from Indigenous nations), this is challenged by the danger of interpretation unmoored from how a principle contemporarily informs how Indigenous societies coordinate the lives of their citizens. In order to alleviate this danger, it is necessary that any analysis of stories be presented and reviewed by the citizenry to whom the stories belong.

\section{Conclusion}

Working through the potential conflicts that the overlapping operation of common law and Indigenous legal practices create provides an opportunity for non-Indigenous Yukoners to access, understand, and walk in a correct way toward Indigenous legal traditions. This is a substantive form of reconciliation. It is beyond the reflection offered in this commentary to speculate on the futures of Indigenous legal ordering in these spaces in the Yukon. However, the political and legal arrangements between Yukon First Nations and the federal and territorial 
governments provide a unique opportunity (in relation to the rest of Canada) for non-Indigenous Yukoners to observe, acknowledge, and respect Indigenous laws and legal traditions. The Yukon is in an inherently unique and advantageous position to consider and take up the wealth of legal traditions in the territory, due to the close relations of Indigenous and non-Indigenous lifeworlds in the territory. In my brief experiences with the Yukon legal community as well as with the Territorial Court and Supreme Court, there is an implicit understanding of this plurality, and how contextualizing judicial reasoning within this plurality strengthens relations as a whole. The approaches outlined in this commentary are only a reference point for non-Indigenous Yukoners and legal practitioners in the territory to further draw upon the wealth that the plurality of legal systems in the territory provide.

\section{Notes}

1. Hadley Friedland \& Val Napoleon, "Indigenous Legal Traditions: Roots to Renaissance" in Markus Dubber \& Tatjan Hornle, eds, The Oxford Handbook of Criminal Law (London: Oxford: Oxford University Press, 2014).

2. Ibid.

3. I borrow the term "lifeworld" from Aaron Mills in Aaron Mills, "The Lifeworlds of Indigenous Law: On Revitalizing Indigenous Legal Orders Today” (2016) 61:4 McGill Law Journal 847 at 855, online: <http://www.canlii.org/t/29qk >. Mills's full contribution is instructive to what I am seeking to express here, as he impresses the importance of Anishnaabeg lifeworld to inform what we think of as a constitution. Mills states that "any constitutional order ... reflects an understanding of what a person is and what community is, and pursues a vision of freedom determined by these understandings for its members. It's only against a shared set of understandings that law comes into the world."

4. For other examples of Indigenous constitutionalisms see: John Borrows, Freedom and Indigenous Constitutionalism (University of Toronto Press: Toronto, 2016) [Borrows, Freedom]; Mills, ibid.

5. See Val Napoleon, “Thinking About Indigenous Legal Orders” in René Provost \& Colleen Sheppard, eds, Dialogues on Human Rights and Legal Pluralism (New York: Springer, 2013) at 234.

6. For example, the Samson Cree Nation has affirmed in writing its constitutive principles of pimohciwin (Cree way of life), wahkotowin (kinship), sakitowin (love), and tapwewin (honesty) as directive teachings on how their leadership governs. Online: <http://samsoncree.com/aboutus>.

7. Protocols surrounding ceremonial practices are examples of customary norms in Plains Cree societies. A good philosophical exploration of the importance of these protocols to the legal practice of ceremonies is found in Claire Poirer, "Drawing Lines in the Museum: Plains Cree Ontology as Political Practice” (2011) 53 Anthropologica 291 at 294, online: <https://www.jstor.org/stable/41473880>. 
8. See Rob Innes, Elder Brother and the Law of the People: Contemporary Kinship and Cowessess First Nation (Winnipeg: University of Manitoba Press, 2013).

9. wahpimaskwasis (Little White Bear) Janice Makokis, nehiyaw iskwew kiskinowâtasinabikewina-paminisowin namôya tipeyimisowin: Cree Women Learning Self Determination Through Sacred Teachings of the Creator (MA Thesis, University of Alberta, 2005) [unpublished] at 10.

10. See the work of Plains Cree artist George Littlechild in George Littlechild et al, In Honour of Our Grandmothers (Penticton: Thetus Books, 1994).

11. Makokis, supra note 9 at 10 .

12. Ibid at 2 .

13. See Innes, supra note 8 at 73-76.

14. Kiera Ladner, "(Re)creating Good Governance, Creating Honourable Governance: Renewing Indigenous Constitutional Orders," Paper presented at the Annual Conference of the Canadian Political Science Association (Ottawa, May 2009), online: <https://www.cpsa-acsp.ca/papers-2009/Ladner1.pdf > at 4.

15. Makokis, supra note 9 at 3 .

16. Both the Canadian and American dialogues on constitutional interpretation have had to deal with (and have settled in different manners) the tensions between originalist and "living-tree" approaches to their respective constitutions. See Borrows, Freedom, supra note 4.

17. For example, see Aaron Mills's conception of Anishnaabe constitutionalism in Mills, supra note 3.

18. Reference re Secession of Quebec, [1998] 2 SCR 217 at para 148.

19. Ibid.

20. Borrows, Freedom, supra note 4 at 105.

21. Ibid at 106 .

22. As Eve Darian Smith suggests, this increasing reliance upon written and positivistic law has created a system where: "(1) that legal meaning is found strictly within legal texts, reports, and documents, (2) that law is almost wholly addressed in formal legal arenas such as courtrooms, governmental assemblies, and places of legal adjudication, (3) that law should be described in the vocabularies of European-based languages, primarily English, and (4) that common law and civil law legal systems are preferred." See Eve Darian-Smith, "Producing Legal Knowledge," in Eve Darian-Smith, ed, Laws and Societies in Global Contexts: Contemporary Approaches (Cambridge: Cambridge University Press, 2013) 97 at 108.

23. Borrows, Freedom, supra note 4 at 110.

24. Ibid at 110. For one, Borrows, as do many other jurists, notes that the rights recognition model that informs s. 35 jurisprudence limits the rights of Indigenous peoples and societies to historical and site-specific practices.

25. See generally Brian Tamanaha, "An Analytical Map of Social Scientific Approaches to the Concept of Law" (1995) 15 Oxford Journal of Legal Studies 501, online: <https://doi.org/10.1093/ojls/15.4.501>. 
26. For example, see the Great Law of Peace written by the Haudenosaunee, which was first originally written on wampum belts. As paper texts became more prevalent in North America, the Great Law of Peace was published on paper. See Francis Jennings, The Ambiguous Iroquois Empire (New York: WW Norton, 1990); Borrows, Canada's Indigenous Constitution (Toronto: University of Toronto Press, 2010) at 72-75.

27. For an analytical breakdown of modern written constitutions by First Nations, see Christopher Alcantara \& Greg Whitfield, "Aboriginal Self-Government through Constitutional Design: A Survey of Fourteen Aboriginal Constitutions in Canada" (2010) 44:2 Journal of Canadian Studies 122, online: <https://doi. org $/ 10.3138 /$ jcs.44.2.122>.

28. Ibid at $124-125$.

29. See Hadley Friedland, Reflective Frameworks: Methods for Accessing, Understanding and Applying Indigenous Laws (2012) 11:1 Indigenous Law Journal, online: < $\underline{\text { https:// }}$ jps.library.utoronto.ca/index.php/ili/article/view/27628>.

30. Ibid at 18 .

31. Matthew Fletcher, "Rethinking Customary Law in Tribal Court Jurisprudence" (2016) Michigan State University College of Law, Indigenous Law and Policy Centre Occasional Paper Series, online: <http://www.law.msu.edu/indigenous/ papers/2006-04.pdf> at 41 .

32. As discussed in Friedland, supra note 29 at 41.

33. See generally, John Borrows, "Indigenous Legal Traditions in Canada" (January 2006) Report for the Law Commission of Canada, online: <http://publications. gc.ca/collections/collection 2008/lcc-cdc/JL2-66-2006E.pdf> at 7.

34. See Darcy Lindberg, "kihcitwâw kîkway meskocipayiwin (sacred changes): Transforming Gendered Protocols in Cree Ceremonies through Cree Law (LLM Thesis, University of Victoria, Faculty of Law, 2017) [unpublished].

35. See Heidi Stark, "Changing the Treaty Question" in John Borrows \& Michael Coyle, eds, The Right Relationship: Reimagining the Implementation of Historical Treaties (Toronto: University of Toronto Press, 2017) at 274.

36. Friedland, supra note 29 at 21-22.

37. Ibid at 22 .

38. Ibid.

\section{Author}

Darcy Lindberg is assistant professor in the Faculty of Law at the University of Alberta. 